\title{
Ildikó Limpár
}

\section{Seymour}

\section{Key to Salinger's Philosophy of Composition and Publication}

\begin{abstract}
In his rare interviews, Salinger explains his choice of retiring from publication as a private person; his stories, in contrast, provide an insight into the author's intellect, and allow us to realize the artist's motivation for writing only for the sake of writing. The present paper focuses on the artistic principles of the two author characters in Salinger's oeuvre, Buddy and Seymour Glass, considering them as the alter-ego and the artistic ideal of the author, respectively. First the Glass's way of communication is presented, emphasizing the importance of key concepts, such as perfection and the method of not-aiming. Then Seymour's suicide is investigated, making the point that it should not be considered as the poet's act aiming at ultimate perfection in his existence but as an act of a person seriously harmed by his war experiences. Therefore, Seymour is a contradictory character, shown as a perfect artist and a failed man. Ultimately, the paper suggests that Salinger saw the contradiction between his ideal and reality's limitations, which explains his attitude to publishing and his gesture of granting Buddy the authorship of his own Seymour stories.
\end{abstract}

We know of only few authors who resisted the temptation of publication when they had the chance to show the world what they had in their drawers. Emily Dickinson, for instance, claimed that "Publication - is the Auction / of the Mind,"1 fearing that the process of publishing might damage the integrity of her art. A century later, acclaimed novelist J. D. Salinger decided that publication is the auction of private life, and chose not to publish his texts in the future despite staying an active writer. "There is a marvelous peace in not publishing. ... Publishing is a terrible invasion of my privacy."2 In his rare interviews, Salinger explains his choice of retiring from publication as a private person; his stories, in contrast, provide an insight into the author's intellect, and allow us to realize the artist's motivation for writing only for the sake of writing.

1. Emily Dickinson, "Poem 704," in The Complete Poems, ed. Thomas H. Johnson (London: Faber and Faber, 1975), ll. 1-2.

2. Lacey Fosburgh, “J. D. Salinger Speaks About his Silence," New York Times (3 November, 1973), 25 March, 2010 < http://www.nytimes.com/books/98/o9/13/specials/salingerspeaks.html?_r=2>.

The AnaChronisT 15 (Winter 2010): 104-116 ISSN 1219-2589 
The Glass family Salinger writes about in his fiction has the poet Seymour in its focal point. The much beloved and sadly deceased brother comes alive through the words of the other author in the family, Buddy. The investigation of the two authors' characters in Salinger's works of art reveals Salinger's "philosophy of composition," taken that Buddy appears as Salinger's alter ego, while Seymour is presented as Buddy's - that is, Salinger's - ideal as an author.

Seymour is the admired eldest brother, an outstanding talent even in this extraordinary family of Glasses, where each of the seven children was a regular guest on a radio quiz program "It's a Wise Child." The children may be very different as far character, but they definitely agree on one thing: Seymour was "all things to his brothers and sisters. ... he was our blue-striped unicorn, our double-lensed burning glass, our consultant genius, our portable conscience, our supercargo, and our one full poet," as Buddy enumerates. 3 To play with the words: the Glasses are proud of their special burning glass - the metaphoric phrasing of Seymour as focal point and as someone who is capable of transforming what he interacts with - and they also agree on Seymour's otherwise dividing character, as if they were looking at the world - or, at least, their special world, Seymour - through the same glasses.

Seymour and his siblings share an emotional-intellectual microcosm that often seems impenetrable to outsiders. The bond that connects them is invisible like glass, and is based on Seymour, who, in "A Perfect Day for Bananafish," turns out to be fragile like glass, and falls apart through his act of suicide. Buddy seems determined to collect the splinters and assemble the pieces of his memory in order to reproduce the family's lost treasure and to present it to the world, thus providing a passage for the outsiders into the initiated world of the Glasses. Yet, as he is also member of the family, he uses the Glasses' ways of communication to do so, which reinforces the impassable nature of the borderline between the Glasses and the rest of the world instead of providing a bridge between the two spheres. In fact, one of the central themes of Salinger's Seymour stories is the conflict generated by the difference in communication between what Ihab Hassan calls "Responsive Outsiders," represented by members of the Glass family, and "Assertive Vulgarians," where Muriel and her family belong.4 Seymour's suicide proves this conflict irresolvable, despite the fact that Seymour, as Eberhard Alsen points out, does take the important step of trying to bridge his intellectual world and Muriel's more superficial,

3. All parenthesised references are to this edition: J. D. Salinger, "Raise High the Roof Beam, Carpenters," in Raise High the Roof Beam, Carpenters and Seymour: An Introduction (New York: Penguin Books, 1983), 9-71, p. 83.

4. Ihab Hassan, Radical Innocence: Studies in the Contemporary American Novel (Princeton: Princeton UP, 1961), p. 261. 


\section{ILDIKÓ LIMPÁR}

material, yet, from a certain perspective, more human world by marrying the girl. 5 Therefore, when intending to break through the thick glass separating the worlds of intellectual depth and shallowness, we need to learn the mode of communication the Glasses used among one another, searching for hints that Buddy scattered in his text. Understanding the kind of communication that originates from Seymour's intellect will help us restore the picture of Seymour as an artist, ultimately revealing Salinger's principles of art.

"Raise High the Roof Beam, Carpenters" begins by recalling the night when Seymour read out the Taoist tale of Kao's finding the superlative horse to his sister Franny (9-10). The tale is fundamental in understanding the core of the novelette, creating a connection between the Taoist tale's protagonist Kao and Buddy's protagonist, Seymour, based on their abilities to see beyond externals and recognize inner qualities. ${ }^{6}$ While the parallel does indeed offer an explanation for Seymour's choice of marrying Muriel - a choice which is unperceivable for others, including Buddy himself - the circumstances in which the tale is used and re-used are also of great importance. The Taoist tale is chosen by Seymour to communicate with his ten-month-old sister, who is crying at night yet is obviously not hungry; twenty years later, Buddy turns the same tale into a parable in order to communicate the most important qualities he attaches to Seymour's character. Although the tale as parable is a conventional technique of communication in literature, it is also a method that demands strong participation on the reader's part; thus in no way can we judge it a simple way of communication. Seymour's use of the tale, however, is more striking. As an explanation for his choice of reading out a Taoist tale to Franny, he tells Buddy that "[babies] have ears. They can hear" (9). As Dennis L. O'Connor argues, "[b]y alluding to a biblical injunction about childlike reception of the word

of God, Seymour stresses the seriousness of his action, the sacredness of the Taoist text, and the religious pluralism that characterizes Salinger's fiction."7 Buddy's and Seymour's alternative uses of the Taoist tale point to the Glasses' atypical methods of communications.

Buddy presents the Taoist tale as a parable of what is going to follow, that is, the story of Seymour's wedding day. He places the tale at the beginning of his recollections, and he invites his readers to interpret Seymour's story in the light of the Taoist tale when he writes: "Since the bridegroom's permanent retirement from the

5. Eberhard Alsen, "Raise High the Roofbeam, Carpenters' and the Amateur Reader," Studies in Short Fiction 17 (1980) 39-47, p. 47.

6. Alsen, "Raise High,” p. 46 and Dennis L. O'Connor, “J. D. Salinger's Religious Pluralism: The Example of Raise High the Roof Beam, Carpenters," The Southern Review 20.2 (1984) 316-32, pp. 319-22.

7. O'Connor, p. 317. 
scene, I haven't been able to think of anybody whom I'd care to send out to look for horses in his stead" (11). At the start of "Carpenters," he calls for interpretation from the readers; then he writes of the wedding day, on which Seymour, the bridegroom, did not turn up; in the end, he concludes with an unexplained statement that again demands interpretation. The framework Salinger/Buddy places Seymour's story within makes one of the themes of his text materialize: the amateur's reader's difficulty in understanding the Glasses' way of communication.

"Carpenters" ends with Buddy's peculiar statement on a cigar end: "I still rather think [this] cigar end should have been forwarded on to Seymour, the usual run of wedding gifts being what it is. Just the cigar, in a small, nice box. Possibly with a blank sheet of paper enclosed, by way of explanation" (71). Buddy offers no other explication for this statement, either, except the blank sheet of paper that follows these lines. What he wants to communicate with a blank sheet of paper is open for interpretation.

It is the deaf-mute relative of the bride who leaves the cigar end in Buddy's apartment on the day when Seymour is to marry Muriel, but instead, he elopes with her. The three sentences quoted above reveal that the cigar end has a clear meaning for Buddy, a meaning that an enclosed blank sheet of paper may enlighten - at least, to Seymour. When it occurs to Buddy that the cigar end may pass as a wedding gift, this object of consumption, deprived of its essence, this piece of waste, is spiritualized and begins to carry a meaning that makes it suitable for functioning as a constant reminder of the wedding that does not actually take place on that day. In Buddy's mind, the cigar end transforms into a symbol.

As Buddy notes, the cigar end is the indicator of the smoker's existence (7071). It communicates about existence in a curious way: the cigar end signals the non-existence of the smoked cigar, and this non-existence demonstrates the existence of someone who is not present. We may explain this absurd symbol in a number of ways. For one, the cigar end may stand for the behavior of the bridegroom, who leaves the waste behind himself as the old man leaves his cigar end. The object considered as a gift, on the other hand, may emphasize that this society - the bride's cultural environment - may contribute to the wedding only with waste, as it does not represent real value, at least in Buddy's view. The cigar end may also be considered as a memento of the irrevocable consequence of an act - that is, Seymour's refusal to turn up at the wedding. The incomplete cigar may be regarded as a Freudian joke (supposing that Buddy has a sense of humor), referring to Muriel's overpsychologized mother, who thinks Seymour is a latent homosexual; finally, knowing the Glass family members, who were fed on literature and who like communicating via literary quotations, we may even assume that the cigar end could evoke literary allusions they are familiar with: "the burnt-out ends of smoky days" is one possible 


\section{ILDIKÓ LIMPÁR}

reference, alluding to Eliot, whose poetry was well-known by several family members, as it becomes clear from other stories. ${ }^{8}$

We could go on widening the symbol's horizon of elucidation, accepting the relevance of all possible religious interpretations that O'Connor learnedly enumerates, ${ }^{9}$ but what exactly Buddy has in mind when he equals the cigar end with a wedding gift, we will never learn. However, it appears that all the possible interpretations rely on the idea that the cigar end may be taken as the image of lack. Yet, if the significance of the cigar end lies in the fact that it is lacking, then it is the lack itself that transforms into something. Therefore, the cigar end may actually be taken as the symbol of transformation, the change from waste into a symbol, that is, value. More precisely, the cigar end indicates the possibility of seeing treasure in waste. The significance of this object relies not exclusively in the various interpretations that it has triggered, but rather in its being a signifier of seeing more in general terms. This is a piece of waste in which one may find value - if he is capable of recognizing the value. This presupposes a special mode of seeing, putting on, metaphorically speaking, the Glasses' glasses.

The key to understanding this "sea-change"10 to allude to another great poet, the tool of perceiving the transformation of what is decayed into "something rich and strange,"11 is the blank sheet of paper, the "vehicle of enlightenment," ${ }_{12}$ which tries to give an explanation by its sheer existence, as it has no other information to display. Thus the lack of information becomes information, and waste becomes value. Seymour would understand, since he sees more, as his name also suggests. (That, is, he saw more. He has been dead for seven years when Buddy writes the story of his wedding day. His non-existence is present as literary value, though: without his death Buddy would not have written "A Perfect Day for the Bananafish," and he would not feel the urge to write even more of Seymour. This is another level of understanding that the transformation that the cigar end indicates.)

8. When Seymour says "mixing memory and desire" in J. D. Salinger, "A Perfect Day for Bananafish," For Esmé - with Love and Squalor (New York: Penguin Books, 2010), 1-12, p. 9, he quotes T. S. Eliot, "The Waste Land," Collected Poems 1909-1962 (London: Faber and Faber, 1974), 61-86, 1. 3, which suggests that both he and Buddy knew Eliot's poetry. Franny also comments on Eliot in J. D. Salinger, "Franny," Franny and Zooey (New York: Penguin Books, 1978), 9-39, p.10.

9. O’Connor, pp. 327-32.

10. William Shakespeare, The Tempest, ed. Frank Kermode (The Arden Shakespeare, Walton-on-Thames, Surrey: Thomas Nelson, 1998), 1.2.403.

11. Shakespeare, 1.2.404.

12. O'Connor, p. 330. 
If we want to see even more in the cigar end we must consider both the activity and the person related to it. The cigar end is the waste produced by smoking, a recurring motif in Salinger's oeuvre. As Gordon E. Slethaug observes, "to smoke in Salinger's novels is often to think deeply and spiritually. The act of inhaling indicates a meditative process, a process whereby one develops insight in a situation where insight and wisdom come none too easily." ${ }^{13}$ In addition, the smoker, the deaf and dumb person, presents a number of analogues with Seymour, all coming from a mode of existence that distinguishes him from the average. From the Taoist perspective, "the old man resembles the Taoist ideal of the Perfect Man who "has no self. ... As the Nameless One, he is egolessness and silence incarnate,"14 just as Buddy sees his ideal, Seymour. The old man's deafness and muteness make him more sensitive to visual perception than others, actually seeing more, just as Buddy claims Seymour does. His alternative mode of communication with the world makes every written word of his emphatic and superior, taking the role of everyday chatting. Thus Muriel's deaf-mute relative counterbalances the family's strongly verbal members, and forms a bridge toward the Glass family, whose members, as we learn, are more reliant on the written word even in their everyday communications, leaving messages on the bathroom mirror, writing letters and diaries, and - last but not least - quoting poetry. Using art as communication completes the parallel between Seymour and the nameless man the moment Buddy identifies the deaf-mute's one word on the paper as poetry (41).

Poetry, as it appears from Buddy's words, comes from perception different from the normal. Art is a way of seeing differently, which, as the old man's example suggests, is also a way of existing differently. The divergence, in this world, appears as lack (which, again, adds to the significance of that left cigar end). The drawn parallel between Seymour and the old man makes Seymour's difference - identified as a psychological deficiency by Muriel's mother - visible by the old man's clearly identifiable deficiencies. Seeing differently is a prerequisite for recognizing real value, that is, the superlative; as a consequence, perfection and deficiency, that is, imperfection, become intertwining concepts. Perfection must include imperfection, or else it will suffer deficiency, which contradicts the concept of perfection. This is an old theological problem: Christian philosophers contemplated this question concerning the nature of God; but the root of the idea appears in the Eastern religions, too, where emptiness and perfection may become synonyms: for instance, the Buddhist “Śūnya or śūnyatā, 'emptiness,' paradoxically denotes fullness." ${ }_{5}$

\footnotetext{
13. Gordon E. Slethaug, "Seymour: A Clarification," Renascence 23 (1971) 115-28, p. 122.

14. O'Connor, p. 323-24.

15. O'Connor, p. 332, italics in the original.
} 


\section{ILDIKÓ LIMPÁR}

Seymour, equally influenced by Christian and Eastern philosophy and religions, ${ }^{16}$ believes that the seemingly perfect must be perfected by imperfection. This idea explains Seymour's otherwise inexplicable acts, which have divided critics. One of the most embarrassing acts that Seymour has ever done is throw a stone at Charlotte Mayhew when he was twelve. As Buddy explains, "[h]e threw it at her because she looked so beautiful sitting there in the middle of the driveway" (69). This is a memory that the bride's family takes as an early proof of Seymour's abnormality, which they take for granted after his not turning up at his own wedding, his excuse being that he was "too happy to get married"(34). The two stories emphasize the near-perfection of the moment to be ruined: Charlotte's looking so beautiful that a stone is needed to spoil her beauty, and the bridegroom's being too happy to celebrate his happiness with his bride. ${ }^{17}$ For what seems perfect is only appearance, preventing us from looking into its depth, appealing to our eyes. Seymour, however, does not let appearance distract his attention. He knows how to see the world, and he reveals his secret in his last haiku.

It is not by chance that the most successful poetic form in Seymour's art is the haiku, the "penultimate expression of the ultimately inexpressible." ${ }^{18}$ As R. H. Blyth explains, "[f]or the reader, every haiku is a kôan, a question in Zen."19 What follows from this statement is that "if these poems are kôan, there is no rational or analytic approach which will bring one enlightenment or understanding. In fact, the mystery behind kôan comes from the sudden intuitive realization that nothing is the answer and everything is," ${ }^{20}$ which is also congruent with the special mode of seeing Buddy attaches to Seymour's character.

Seymour's last poem, a haiku written in Japanese on the afternoon of his suicide, "tells of a little girl on an airplane who has a doll in the seat with her and turns its head around to look at the poet." ${ }^{21}$ As Goldstein and Goldstein observe, "[w] hat is essential ... in the doll poem is the fusion of the real and the unreal, the seeing and non-seeing, the animate world and the inanimate world.... The total harmony of the movement of the girl and the doll's actually seeing what the

16. See O'Connor's article that sheds light on "Salinger's religious pluralism, in terms of his complementary use of Taoist, Buddhist, and Christian thought" (p. 317), especially part III (pp. 327-32).

17. Italics mine.

18. Bernice Goldstein and Sanford Goldstein, "Seymour's Poems," Literature East \& West 17 (1973) 335-48, p. 338.

19. Blyth quoted in Goldstein, pp. 338-39.

20. Goldstein, p. 339.

21. J. D. Salinger, "Seymour: an Introduction," Raise High the Roof Beam, Carpenters and Seymour: An Introduction (New York: Penguin Books, 1983), 75-157, p. 102. 
girl sees." ${ }^{22}$ Although the image does involve the sense of harmony, it also includes just its opposite, the fearful, as could be expected from a real haiku. It is not the girl but her miniature, lifeless doppelgänger that looks at the man. This Gothic image is made even scarier by the movement the doll makes: its head turns exactly as much as to be able to focus on the poet. As it is impossible for the girl to watch both the man and her doll at the same time; the horrifying aspect comes from the realization that there is a latent knowledge that helps the girl adjust her doll's head into the perfect position.

The doll becomes a mediator between the girl and Seymour, just as the cigar end connects the old deaf-mute and Seymour. The doll manifests the different way of seeing, as it watches something with eyes that are made of glass, and, hence, are not for seeing. These are the real Glass eyes, in which Seymour recognizes himself, and with which one can perceive what is essential. The point in this mode of seeing is that the spectator does not turn his eyes toward what is to be seen; instead, the viewer lets an outside force - latent knowledge, sixth sense, divine power - turn his Tiresian look, blind and all-seeing at the same time, toward the view. As follows, not aiming at seeing is what leads us to seeing more. This is the attitude that Seymour applied in all walks of life: "a paradoxical stance of simultaneous identification with but detachment from the task at hand, getting inside the activity and performing it for its own sake and not for the sake of anything outside it, such as winning, asserting one's superiority over another, achieving status." ${ }^{23}$

The doll Seymour writes of in his last haiku expresses a philosophy of art which is deeply rooted in a philosophy of religion. It becomes the image of reaching your goal by "not aiming so much," 24 a fundamental attitude in one's "quest for noknowledge." 25 As Seymour has an outstanding intellect, he knows from his childhood what path he would like to follow and what aim he aspires to. The poetry he produces as an adult nears perfection from the religious-philosophical point of view he has, as the very few examples Buddy mentions demonstrate. ${ }^{26}$ Yet the poems he has written are practically non-existent in the world he lives in, as either the language or the form - or both of them - that Seymour applies makes his poetry un-

22. Goldstein, p. 346.

23. Alfred F. Boe, "Street Games in J. D. Salinger and Gerald Green," Modern Fiction Studies 33.1 (1987) 65-72, p. 71. The importance of Seymour's technique identified as "formlessness" in sports was noted earlier in Gordon E. Slethaug, "Form in Salinger's Shorter Fiction," Canadian Review of American Studies 3 (1972) 50-59, p. 56.

24. Salinger, "Seymour," p. 149.

25. J. D. Salinger, “Zooey,” Franny and Zooey, (New York: Penguin Books, 1978), 43-157, p. 56.

26. For a detailed analysis of Seymour's last haikus, see Goldstein, pp. 342-46. 


\section{ILDIKÓ LIMPÁR}

translatable for those who surround him. His art thus perfectly mirrors his mode of existence: Seymour's life is as untranslatable for others as is his poetry, and only his closest relatives may claim that they understand his acts - artistic and private alike - to a certain extent.

Seymour's last act, taking his own life, is as much of a kôan as his last poem. But does it also aim at perfection, as many critics suggest? Let us make no mistake: stopping the state of imperfection does not necessarily mean reaching perfection. Attaining the zero state, for Seymour, is stopping existence and not fulfilling his life purpose of experiencing nirvana. His suicide is an act of despair coming from his realization that he will never reach what he aspires for even if he does everything within his capacity for it. What hinders him in his fulfillment, however, is still a disputed question.

Critics often identify Seymour's problematic sexual life as a source of his frustration and depression, ${ }^{27}$ and fail to search for the possible reasons why his relationship with his wife may have gone wrong. Getting fed up with "phoniness" is the most we usually get as an explanation of the bananafish parable Seymour entertains Sybil with. The arguments, in addition, are hard to attack, because they do contain the truth: Seymour obviously did have problems within his marriage and he did get tired of the phoney word he lived in. However, there are certain facts that appear easy to overlook and that may help us understand Seymour's decision to commit suicide. In four separate articles Alsen writes of four details concerning Seymour's personality. Putting the four aspects together may illuminate Seymour's choice.

In his article published in 1980,28 Alsen makes it clear that Seymour's decision to marry Muriel reflects his understanding that his search of perfection has alienated him from other people, as well as his hope of being able to bridge his world and his wife's. In Buddy's presentation, Seymour's level of enlightenment at this time appears close to Kao's in the Taoist tale of finding the superlative horse, as he sees in Muriel the hidden value of being non-judgmental. (Another point, irrelevant from the viewpoint of this argument, is that mistaking Muriel's superficiality for being non-judgmental in the Taoist sense may be a grave mistake on Seymour's part.) A year later, Alsen concentrates on the aspect of Hinduism in Salinger's work, specifically investigating the importance of this religion on Seymour's life, and arrives at the conclusion that "[h]is long-term goal being mukti, oneness with God,

27. James E. Bryan, "Salinger's Seymour's Suicide," College English 24 (1962) 226-29; Charles V. Genthe, "Six, Sex, Sick: Seymour, Some Comments," Twentieth-Century Literature 10 (1965) 170-71; Frank Metcalf, "The Suicide of Salinger's Seymour Glass," Studies in Short Fiction 9.3 (1972) 243-46; John Russel, "Salinger's Feat," Modern Fiction Studies 12 (1966) 299-312.

28. Alsen, "Raise High." 
Seymour was in despair when he found that he was unable to stop or reverse his spiritual decline. He therefore ended his life in order to resume his spiritual progress in his next incarnation." ${ }^{29}$ As Alsen claims, the Bananafish story "confirms that Seymour was not a saint when he shot himself and that his suicide and spiritual deterioration were due to his estrangement from and contempt for those who did not share his intellectual and spiritual values." ${ }^{30}$ However, this explanation only partially explicates Seymour's act of suicide, as the reason for his spiritual decline is more complex and is deeply rooted in his war experience, which is overlooked by most critics of Salinger. Actually, we might even say that it was first overlooked or at least underrated by Alsen himself, as he compiled a most useful chronology on Seymour's life in 1978, pointing out Seymour's spiritual decline. ${ }^{11}$ He concludes that Muriel could not be the reason for Seymour's suicide, as his first attempt at suicide happened before the two met. However, Alsen does not give the reasonfor what may have caused Seymour's change of behavior, taking the suicidal attempt obscurely as "the symptom of something else that went wrong." 32 Years later, in his study connecting the nervous breakdowns of Seymour and Sergeant X in "For Esmé - with Love and Squalor," Alsen already highlights the importance of the war theme in Salinger's works, assuming that Salinger's own nervous breakdown due to his war experience served as a model for the two similar cases. 33 Based on Salinger's determining war experience of visiting a liberated concentration camp, Alsen assumes that Seymour's and Sergeant X's mental conditions were also due to a similar experience and not combat fatigue.

The chronological order of the facts we may know of Seymour's life from Buddy's recollections show that things go well for Seymour until 1941, when he is drafted and begins basic training in the army. He slashes his wrists the same year, subsequently begins dating Muriel, and takes up the habit of drinking. We have two data of his life from 1942: he is transferred to a B-17 base in California, and he elopes with Muriel after he fails to appear at the wedding. In 1944 he is transferred to the "European Theater of Operations" and takes part in the occupation of Germany. The following year he has a nervous breakdown, and he needs to be treated in psychiatric wards of the Army hospital for three years. In 1948 he finally flies home to New York, spends a few days with Muriel's family, drives a

29. Eberhard Alsen, "The Role of Vedanta Hiduism in Salinger's Seymour Novel," Renascence 33.2 (1981) 99-116, p. 112.

30. Alsen, "The Role," p. 114.

31. Eberhard Alsen, "Seymour: A Chronology," The English Record 29.4 (1978) 28-30.

32. Alsen, "A Chronology," p. 30.

33. Eberhard Alsen, "New Light on the Nervous Breakdowns of Salinger's Sergeant X and Seymour Glass," CLA Journal 45.3 (2002) 379-87, pp. 384-87. 


\section{ILDIKÓ LIMPÁR}

car into a tree, 34 then goes on a second honeymoon with Muriel to fire a bullet through his right temple in the end.

The change in Seymour's personality takes place around the time of his joining the army, reversing his spiritual development and resulting in an obvious deterioration that manifests itself in depression. The problems that primarily become visible in conflicts with people are connected to Seymour's new experiences, which make him see the world differently. Phoniness may have been difficult for Seymour to tolerate, but he managed to cope with it earlier and he was kind and helpful to other people, as his religion dictated to him, and, most importantly, he seemed to appreciate life. The war makes harm intolerable for him, as it affects his spirit and intellect. The war taints him, and this may actually be the reason why he thinks he has a tattoo on his body, as if he were also marked by the war, just like the Jews who got tattooed numbers on their arms in the concentration camps. In this respect, it is of importance that Seymour, though not a practicing Jew, was born into a half-Jewish family. It is also informative to see how Salinger commented on his most influential war experience: "[y]ou never really get the smell of burning flash out of your nostrils, no matter how long you live," 35 he said, suggesting that the experience becomes part of you, just like a tattoo.

The bananafish parable, then, serves to translate Seymour's war experience rather than his incapacity to cope with the world's phoniness ${ }^{36}$ or his suggested sexual problems. ${ }^{37} \mathrm{He}$ feels entrapped by having had too much of what transforms an ordinary person into a pig: the war that dehumanizes those who get in touch with it. Once you are caught by the war, you can't get out of it because the war makes a permanent change in you. Metaphorically speaking, the effect of the war becomes the extension of your body. Whether you see it as a tattoo or a swollen stomach makes no difference; the point is that you feel it is visible to others - like the woman in the elevator, who, as Seymour imagines, is staring at his feet - and it is impossible to get rid of it.

As Seymour is an artist, he processes his war trauma as he can: he transforms it into a piece of art, making a story out of it, a parable featuring the fantastic

34. Interestingly, this fact is missing from Alsen's chronology, although Muriel's parents take it as a suicidal attempt.

35. Salinger quoted in Alsen, "New Light," p. 379.

36. See, for instance, James Finn Cotter, "A Source for Seymour's Suicide: Rilke's Voices and Salinger's Nine Stories," Papers on Language and Literature: A Journal for Scholars and Critics of Language and Literature 25.1 (1989) 83-98, p. 86 and Anthony Kaufman, " 'Along this road goes no one': Salinger's 'Teddy' and the Failure of Love," Studies in Short Fiction 35 (1998) 129-40, p. 138.

37. See, for instance, Metcalf, who goes as far as accusing Seymour of heterosexual pedophilia, identifying Sybil with the banana in the bananafish parable (Metcalf, p. 246.). 
bananafish. This is a method that enables him to speak of his experience without having to name it, thus distancing himself from it. Yet, when Sybil, modern prophetess of death, claims she has actually seen a bananafish with six bananas, the borderline between art and life breaks, and reality penetrates into the carefully created fiction that served to detach the traumatic experience. Seymour is assured that the world he returned to may not be kept intact from the taint of war. His attempt to treat his war experience as fiction fails, for what he hopes is only imaginary is actually visible to the girl, whom he considers an oracle. $3^{8}$ The moment Sybil identifies with Seymour by visualizing the same phantasm, Seymour also identifies with the mythic Sibylla, whose only wish was to die, as we may learn from T.S. Eliot's "The Waste Land," a line of which Seymour remembers while talking to Sybil.39 The quote not only connects the ancient and the young oracles, but also reinforces the unbearable effect of the war, "The Waste Land" being the most influential poem treating the theme of the emotional-spiritual emptiness resulted fromthe First World War.

It is the war that causes Seymour's spiritual deterioration leading to his death. It is thus not by chance that both the gun he shoots himself with and the book of German poetry he would like Muriel to read are war souvenirs, as James Finn Cotter remarks..$^{\circ}$ These two objects define his post-war life and death, signaling the importance of the war effect on Seymour. And as war is an indigestible experience, it is not in Seymour's powers to reverse his falling apart. Marrying Muriel, in this light, is already a desperate act in which he hopes to succeed in making improvements in his level of existence by giving up "jnana and raja yoga in favor of karma yoga." 41 Muriel, however, may not counterbalance the after-effects of the war.

We may conclude that the primary reason for Seymour's decision to take his own life is the damage the war has done to him. Therefore, his suicide should not be interpreted as part of his artistic achievement. He may have been really one of the few "very nearly nonexpendable poets" of America, ${ }^{42}$ but he failed to become the saint whom Buddy would like him to be. Salinger/Buddy presents an ideal, but the ideal, at the same time, is not granted a life which could be lived in contemporary America. ${ }^{43}$

38. Slethaug calls attention to the importance of Sybil's name (p. 127), but it is Gary Lane who establishes the obvious connection between Sybil and Sibylla from the motto of T. S. Eliot's "The Waste Land" (Garry Lane, "Seymour's Suicide Again: A New Reading of J. D.

Salinger's 'A Perfect Day for Bananafish,'” Studies in Short Fiction 10 [1973] 27-33, p. 30n9). 39. See footnote 8 .

40. Cotter, p. 84.

41. Alsen, "The Role," p. 111.

42. Salinger, "Seymour," p. 103, italics in the original.

43. The same problem is investigated in Salinger's "Teddy," as Kaufman points out. 


\section{ILDIKÓ LIMPÁR}

And while Buddy and his brothers and sisters may entertain the idea that Seymour's life was perfected by his death, Salinger gives us all the clues to conclude differently.

In a series of interconnected stories and novelettes, Salinger presents to us the irresolvable nature of aiming at perfection in various walks of life. He created an ideal character who was admired for his literary achievements by a small circle of learned people. He also created a whole family surrounding his fictional hero, partially identifying with several of them. $44 \mathrm{He}$ knew that it was impossible to reconcile the personality of the perfect artist with reality, but he still wanted to keep his ideal. He therefore wrote about Seymour from Buddy's point of view, suggesting a strong belief in Seymour's perfection, yet giving hints to careful readers which make clear that Salinger could distinguish between reality and the fantasy of the ideal, however painful it was to see the discrepancy between the two.

While critics like to suggest that Salinger's alter ego is Buddy, and thus he only longs for the kind of perfection he associates with Seymour's character, Salinger reaches the desired artistic perfection via the alternative reality that he created. By the gesture of granting Buddy the authorship of the Glass stories, he could actually claim that his best works are the ones he has never written - at least in his fictional world, his artistic nirvana, where he reached the zero state as an artist by writing the most perfect literature he was capable of. For Salinger, publication was not simply the auction of his privacy, as he suggested in his last interview; it was also an aim, and as such, something that destroys achieving artistic perfection. In other words: publication, he thought, was the auction of the mind. Publication is what principally divides Buddy and Seymour as authors, and it is publication that places Salinger between his alter-ego and his ideal of his fictional world, making him a mythic character who was a publisher and non-publisher at the same time.

44. See Max F. Schultz, "Epilogue to Seymour: An Introduction: Salinger and the Crisis of Consciousness," Studies in Short Fiction 5 (1968) 128-38. 